\title{
INTERNET AND SMARTPHONE ADDICTION OF STAFF WORKING IN AN ADOLESCENT ADDICTION TREATMENT CENTER
}

\author{
BİR ERGEN BAĞIMLILIK TEDAVİ MERKEZINNDE ÇALIŞAN PERSONELLERDE İNTERNET VE \\ AKILLI TELEFON BAĞIMLILIĞI
}

\author{
Ömer KARDAS ${ }^{1}$, Burcu KARDAS²
}

\begin{abstract}
AIM: In this study, it was aimed to evaluate the level of smartphone and internet addiction among the staff working in the substance dependence treatment center serving children and adolescents under the age of 18 .
\end{abstract}

MATERIAL AND METHOD: The study included 30 people from different professions working in the child adolescent substance dependence treatment center. Participants were given a sociodemographic data form, Smartphone Addiction Scale-Short Version (SAS-SV) and Short Form of Young's Internet Addiction Test (YIAT-SF).

RESULTS: The mean score of the SAS-SV is $25.3 \pm 11.4$ and YIAT$\mathrm{SF}$ is $19.2 \pm 8.3$. These values are accepted as low-moderate according to literature.. A negative significant correlation was found between age and YIAT-SF $(\mathrm{p}=0.012, \mathrm{r}=-0.454)$. Also, a positive significant correlation was found between both scale scores $(\mathrm{p}<0.001, \mathrm{r}=0.707)$.

CONCLUSION: Internet and smartphone addictions of staff working in the adolescent addiction service were found to be similar to the results of studies conducted with other healthcare professionals. In this regard, there is a need for studies involving staff working in different dependence treatment centers and units.

Keywords: Internet addiction, Smartphone addiction, Addiction in healthcare professionals

\section{ÖZET}

AMAÇ: Bu çalışmada 18 yaş altı çocuk ve ergenlere hizmet veren madde bağımlılığı tedavi merkezinde çalışan personellerde akıllı telefon ve internet bağımlılığı düzeyinin değerlendirilmesi amaçlanmıştır.

GEREÇ VE YÖNTEM: Çalışmaya çocuk ergen madde bağımlılı̆̆ tedavi merkezinde çalışan farklı meslek gruplarından 30 kişi dahil edilmiştir. Katılımcılara sosyodemografik veri formu, akıllı telefon bağımlılı̆̆ı ölçeği kısa formu (ATBÖKF) ve internet bağımlılığ ölçeği kısa formu (İBÖKF) verilmiştir.

BULGULAR: Örneklemin ATBÖKF ortalama skoru 25,3 $\pm 11,4$, İBÖKF ortalama skoru 19,2 $\pm 8,3$ 'tir. Bu değerler literatüre göre düsük-1lımlı kabul edilen değerlerdir. Yas ile İBÖKF arasında negatif yönde anlamlı bir ilişki bulunmuştur ( $\mathrm{p}=0,012, \mathrm{r}=-0,454)$. Her iki ölçek skorları arasında da pozitif yönde anlamlı ilişki bulunmuştur $(\mathrm{p}<0,001, \mathrm{r}=0,707)$.

SONUÇ: Ergen bağımlılık servisinde çalışan personellerin internet ve akıllı telefon bağımlılıkları, diğer sağlık çalışanları ile yapılan çalıșmaların sonuçları ile benzer bulunmuștur. Bu konuda geniş örneklemli, farklı bağımlılık tedavi merkezinde ve birimlerde çalışan personellerin dahil edildiği çalışmalara ihtiyaç bulunmaktadır.

Anahtar sözcükler: İnternet bağımlılı̆̆ı, Akıllı telefon bağımlılığı, Sağlık çalışanlarında bağımlılık

${ }^{1}$ Dicle Üniversitesi Tıp Fakültesi Çocuk ve Ergen Psikiyatri AD, Diyarbakır, Türkiye

${ }^{2}$ Diyarbakır Gazi Yaşargil Eğitim ve Araştıra Hastanesi Çocuk ve Ergen Psikiyatri Kliniği, Diyarbakır, Türkiye

Gelis Tarihi / Submitted : Ekim 2020 / October 2020

\section{Sorumlu Yazar / Corresponding Author:}

Ömer KARDAŞ

Dicle Üniversitesi Tip Fakültesi Çocuk ve Ergen Psikiyatri AD, Sur, Diyarbakır, Türkiye Gsm: +90 5068890696 E-mail: kardasomer@gmail.com
Kabul Tarihi / Accepted : Mayıs 2021 / May 2021

\section{Yazar Bilgileri /Author Information:}

Ömer KARDAŞ (ORCID: 0000-0003-2241-2367),

Burcu KARDAŞ (ORCID: 0000-0002-2912-8097) E-mail: burcu-atar@gmail.com 


\section{INTRODUCTION}

Dependence is a chronic brain disease that progresses with recuperations and recurrences. Generally from the concept of dependence cigarette, alcohol and substance dependence are understood. However, new types of dependence have recently been identified under the name of behavioral dependences. Shopping, exercise, gambling, sex, internet and online game dependence are behavioral dependencies. Studies on these types of dependence are limited and have been increasing recently (1).

The diagnosis of internet and game dependence is still controversial. In the Fifth Edition of The Diagnostic and Statistical Manual of Mental Disorders (DSM5), internet dependence is not included in the main section, but in the supplementary section "Conditions for Further Study" (2). World Health Organization, on the other hand, accepted "online game dependence" as a sub-dimension of internet dependence and determined its criteria (3). The criteria proposed for the diagnosis of behavioral dependences are generally similar to those recommended for other types of dependence. For example, DSM-5 proposes criteria for internet dependence as; "being too busy with internet games, deprivation, tolerance, unsuccessful efforts to quit playing internet games, despite the fact that psychosocial problems are known, continued excessive internet usage, loss of interest, decreased interest in past hobbies and entertainment (except playing an internet game), playing an internet game to alleviate dysphoric mood or to avoid this condition, deceiving the family, therapist and other people about the time of playing internet games, endangering or losing an important relationship, job, education or career opportunities due to playing an internet game" (1).

The prevalence of internet dependence in society varies between $6-14 \%$. The prevalence in studies conducted in Turkey has ranged between 1-19\% (1).The difference of epidemiological data is resulted from the non-standard diagnostic criteria and measurement instrument. The number of studies investigating internet and smart phone use in healthcare professionals is limited. In a study involving 420 nursing students in Italy; Internet dependence and pathological gambling levels were investigated. In this study, internet dependence rate was reported as $8.8 \%(4)$. The prevalence of studies on smartphone dependence varies between 9.3$48 \%(5-7)$. The fact that the range is so wide is that diagnostic criteria and measurement instruments are not standard, as in internet dependence. In a study involving sixth grade students of the medical faculty, the frequency of smartphone dependence was found as $36.5 \%$ (8). In another study involving medical students in India, the frequency of smartphone dependence was reported as $24.6 \%$ (9).

In dependence literature, it is seen that cigarette, alcohol and substance use are generally examined in studies related to healthcare workers. The number of studies investigating internet and smartphone dependence is limited. According to our research this study is the first in this field. Addition, no study was found that included staff working in the dependence treatment center in English literature. In this study, it is aimed to measure the internet and smartphone usage levels of the staff working in an adolescent dependence treatment center and to discuss the results of the measurements with the literature.

\section{MATERIAL AND METHOD Participants}

The study contains staff who volunteer to participate in the research in the Child and Adolescent Substance Treatment Center (CEMATEM) in Diyarbakır/ Turkey. Criteria for inclusion in the study is being literate, working at the center for at least 6 months and volunteering to participate in the study. All the 30 personnel working at ÇEMATEM were included in the study because they were in line with the criteria. All the staff working in the center were included in the study.

\section{Procedure}

Socio-demographic data form, internet addiction scale and smartphone addiction scale were administered to participants. The participants' self-reports were based on. For this research, approval from the ethics committee of Diyarbakır Gazi Yaşagil Education and Treatment Hospital was received on 25.10.2019, desicion no: 357. Written confirmation was obtained that they agreed to participants in the study

\section{Measures}

Sociodemographic data form: It is a form prepared by the researchers and includes the characteristics of the participants such as age, marital status, profession, educational level.

Smartphone Addiction Scale-Short Version (SAS-SV): SAS-SV developed by Kwon et al. (10), measures the risk of smartphone dependence in adolescents, consists 10 items, and is evaluated with a six-point Likert rating. Scale items are scored from 1 to 6 . Scale scores range from 10-60. As the score obtained from the test increases, the risk for addiction is considered to increase. The scale has one factor and it does not have any subscales. In the Korean sample, the cut off score was 31 for men and 33 for women. A validity and reliability study for the Turkish version was carried out by Noyan et al (11). There is no cut off score in the Turkish version.

Short Form of Young's Internet Addiction Test (YIATSF): The scale developed by Young and converted into short form by Pawlikowski et al. consists of 12 items and is a five-point Likert- type ( $1=$ Never, $5=$ Always $)$ $(12,13)$. The instrument was adapted to Turkish by Kutlu et al. in 2006 (14). The results obtained from the validity and reliability studies indicate that the Short Form of Young's Internet Addiction Test is valid and reliable. There are no reverse scored items in the scale. 
High scores from the scale indicate that the level of internet addiction is high.

\section{Statistical Analysis}

The data obtained from the study were recorded in the SPSS 22.0 program. Normality test was used for mean scale scores. Spearman correlation test was used to look at the relationship between mean scores that are not normally distributed.

\section{RESULTS}

The total number of participants included in the study is 30 ( 27 men, 3 women). The average age is 40 \pm 7.6 years $(\min =30, \max =57)$. The median working time of the working group at ÇAMATEM is 42.4 months $(\min =6, \max =144)$. Sociodemographic data are detailed in Table-1.

The number of people using smart phones is 28 (93.3\%) and using non smartphones is $2(6.7 \%)$. The number of internet and computer users is $18(60 \%)$ and the number of those who do not use is $12(40 \%)$. The short form average score of the internet addiction scale of the sample is found $19.2 \pm 8.3\left(\min =12, \max _{-}=51\right)$, and the average score of the smartphone addiction scale was $25.3 \pm 11.4(\min =10, \max =52)$. While the average score of YIAT-SF of 27 (90\%) participants was 30 and below. YIAT-SF and SAS-SV scale scores are given in Table-2.

When the relationship between life and age is examined, a negatively significant relationship is found between YIAT-SF and age $(\mathrm{p}=0.012, \mathrm{r}=-0.454)$. However, there is a positively significant relationship between the scores which obtained from both scales $(\mathrm{p}<0.001, \mathrm{r}=0.707)$. Relationship results with other variables are detailed in Table-3.
Table-2. Averages of YIAT-SF and SAS-SV scale scores of smartphone and internet use

\begin{tabular}{|l|c|c|c|}
\hline & & $\mathrm{n}$ & $\%$ \\
\hline Smartphone use & Yes - & 28 & 93.3 \\
\hline \multirow{3}{*}{ Internet use } & No & 2 & 6.7 \\
\hline \multirow{2}{*}{ YIAT-SF score } & Yes & 18 & 60 \\
\hline
\end{tabular}

YIAT-SF

score $($ mean $\pm \mathrm{SD})$

$19.2 \pm 8.3$

SAS-SV

score (mean $\pm \mathrm{SD})$

$25.3 \pm 11.4$

YIAT-SF: Short Form of Young's Internet Addiction Test,

SAS-SV: Smartphone Addiction Scale-Short Version

Table-3. The relationship between the average scores of YIAT-SF and SAS-SV with age and amount of cigarettes

\begin{tabular}{|l|c|c|} 
& $\mathrm{r}$ & $\mathrm{p}$ \\
\hline YIAT-SF-Age & -0.454 & $0.012^{\star *}$ \\
\hline $\begin{array}{l}\text { SAS-SV-Age } \\
\text { YIAT-SF- Amount of }\end{array}$ & -0.337 & 0.374 \\
$\begin{array}{l}\text { cigarettes } \\
\begin{array}{l}\text { SAS-SV-Amount of } \\
\text { cigarettes }\end{array}\end{array}$ & 0.394 & 0.146 \\
\hline YIAT-SF-SAS-SV & 0.178 & 0.542 \\
\hline
\end{tabular}

Spearman correlation test, $\mathrm{p}<0.05$, r: Correlation coefficient YIAT-SF: Short Form of Youngs Internet Addiction Test, SAS-SV: Smartphone Addiction Scale-Short Version

\section{DISCUSSION}

In this study, it is aimed to investigate internet and smart phone addiction in staff working in an adolescent

Table-1. Sociodemographic information of participants $(\mathbf{n}=\mathbf{3 0})$

\begin{tabular}{|c|c|c|}
\hline \multicolumn{2}{|c|}{ Age (years) (median) (min-max) } & $40 \pm 7.6(30-57)$ \\
\hline \multirow{2}{*}{ Gender $[\mathrm{n}(\%)]$} & Male & $27(90)$ \\
\hline & Female & $3(10)$ \\
\hline \multirow{2}{*}{ Marital Satatus [n (\%)] } & Married & $27(90)$ \\
\hline & Single & $3(10)$ \\
\hline \multirow{2}{*}{ Smoking status $[\mathrm{n}(\%)]$} & Current smoker & $15(50)$ \\
\hline & Non-smoker & $15(50)$ \\
\hline \multicolumn{2}{|c|}{ The amount of daily smoking (cigarettes/day) (median) (min-max) } & $19(10-30)$ \\
\hline \multicolumn{2}{|c|}{ Working time (month) (median) (min-max) } & $42.4(6-144)$ \\
\hline \multirow{3}{*}{ Educational Level [n (\%)] } & Primary-middle school & $3(10.0)$ \\
\hline & High school & $13(43.3)$ \\
\hline & Bachelor-Master Degree & $14(46.7)$ \\
\hline \multirow{3}{*}{ Profession $[\mathrm{n}(\%)]$} & Doctor-Psychologist-Social worker-Nurse & $10(33.3)$ \\
\hline & Technical-security-cleaning-computing staff & $15(50.0)$ \\
\hline & Administrative staff and teacher & $5(16.7)$ \\
\hline
\end{tabular}


dependence treatment center. The rate of those using smart phones is $90 \%(n=28)$. Average score of the Short form of smartphone dependence scale SAS-SV was found $25.3 \pm 11.4$. This score is similar to the average score of the study in which the validity and reliability of the scale was performed. In the same study, the mean score of nursing students' scale was found 26.9 (11). In another study that included nursing students in Turkey, it has examined the relationship between communication skills with smart phone dependence. In the study using smartphone dependence scale, the scale score was found below the average (15). In a study in which nursing students were included and SAS-SV was used, the mean scale score was found close to our study (27.9) (16). In a study involving nursing students in Korea, 324 cases were evaluated. In the study using smartphone dependence inventory, the scale score was found below the average (17). According to our search, no study was found in the literature in which personnel working in addiction treatment centers were evaluated in terms of smartphone addiction.

Internet-personal computer usage rate of the sample is $60 \%(\mathrm{n}=18)$. The average score of the internet dependence scale short form YIAT-SF is measured as $19.2 \pm 8.3$. The scale has no cut-off point. The highest score that can be obtained from the scale is 60 . While the average score of $27(90 \%)$ participants was 30 and below; It is over 30 in $3(10 \%)$ people. In our study, the relationship between age and the mean of YIAT-SF is found significant ( $\mathrm{p}: 0.012$ ). Young's internet addiction scale was used in a study evaluating 100 new graduates from medical faculty. In this study, the mean scale score of the majority of the participants $(87 \%)$ is evaluated at a low (moderate) level. There is no significant relationship found between age and scale score (18). In a study in which the relationship between psychological tension and internet dependence was evaluated and nursing students were included; It was reported that $38 \%$ of the participants were low and $51 \%$ were moderately dependent (19). In a large sample study involving medical students, the mean scores of the participants were evaluated at a moderate level. Similar to our study, in this study, it has been shown that there is a significant negative relationship between age and internet dependence scale score (20). In a study involving 3224 people aged between 9-25 years, factors related to internet dependence were examined. In this study, a positive correlation has been found between age and score from internet dependence scale. It can be thought that being different from our study is that the group included in this study consists of children, young and young adults (21). Similarly in our study; In the validity and reliability study of SAS-SV, a positive correlation has been found between internet dependence and smartphone dependence scale scores (11). In a study investigating the effect of internet dependence on smartphone dependence among adolescents, it has been reported that there was a significant relationship between internet dependence and smartphone dependence (22).

\section{CONCLUSIONS}

In this study, it is aimed to evaluate the level of smart phone and internet addiction among the staff working in the substance dependence treatment center serving children and adolescents under the age of 18. SAS-SV and YIAT-SF average scale scores are similar to other studies conducted among healthcare professionals. Similar to the literature, a negative correlation is found between age and YIAT-SF, and a positive relationship between SAS-SV and YIAT-SF. Additionally, our study is the first in the literature in terms of evaluating the internet and smartphone dependences of the staff working in the dependence treatment center. The limitations of the study are that; the control group are not included, the different units staff are not included, the number of samples is small, the terms of use of the smartphone and the internet are not observed, and different sociodemographic variables are not added. In this regard, there is a need for studies involving staff working in different dependence treatment centers and units.

\section{REFERENCES}

1.)Dinç $M$, Ögel $K$. İnternet bağımlılığı. Bağımlılık tanı tedavi önleme. Öztürk M, Ögel K, Evren C, Bilici R (editörler) 1. Baskı. İstanbul: Yeşilay Yayınları, 2019;703-18.

2.)Bozkurt H, Şahin S, Zoroğlu S. İnternet bağımlılığı: Güncel bir gözden geçirme. J Contemp Med 2016; 6: 235-47.

3.)World Health Organization. International statistical classification of diseases and related health problems (ICD-11): New release. World Health Assembly; Geneva, Switzerland: 2019. Available from: https://www.who.int/news-room/spotlight/internationalclassification-of-diseases. Accessed on: 26 May 2019.

4.)Comparcini D, Simonetti V, Galli F, et al. Gioco d'azzardo patologico e dipendenza da internet tra gli studenti infermieri: uno studio pilota. Pathological gambling and internet addiction among nursing students: a pilot study. Prof Inferm. 2018;71:19-29. 5.) Yahyazadeh S, Fallahi-Khoshknab M, Norouzi K, et al. The prevalence of smart phone addiction among students in medical sciences universities in Tehran 2016. J Nurs-Midwifery. 2017;26:1-9. 6.) Halayem S, Nouira O, Bourgou S, et al. The mobile: a new addiction upon adolescents. Tunis Med. 2010;88:593-6.

7.)Aljomaa SS, Al Qudah MF, Albursan I S, et al. Smartphone addiction among university students in the light of some variables. Comput Human Behav. 2016;61:155-64.

8.)Alhazmi AA, Alzahrani SH, Baig M, et al. Prevalence and factors associated with smartphone addiction among medical students at King Abdulaziz University, Jeddah. Pak J Med Sci. 2018;34:984-8. 9.) Jain P, Gedam SR, Patil PS. Study of smartphone addiction: prevalence, pattern of use, and personality dimensions among medical students from rural region of central India. Open J Psychiatr Allied Sci. 2019; 10:132-8.

10.)Kwon M, Kim DJ, Cho H, et al. The smartphone addiction scale: development and validation of a short version for adolescents. PloS One. 2013; 8:e83558.

11.)Noyan CO, Enez Darçın A, Nurmedov S, et al. Akıllı Telefon Bağımlılığı Ölçeğinin Kısa Formunun üniversite ögrrencilerinde Türkçe geçerlilik ve güvenilirlik çalışması. Anatolian Journal of Psychiatry/Anadolu Psikiyatri Dergisi. 2015;16: 73-81.

12.)Young KS. Caught in the net: How to recognize the signs of internet addiction and a winning strategy for recovery. New York: John Wiley \& Sons, 1998. 
13.)Pawlikowski M, Altstötter-Gleich C, Brand M. Validation and psychometric properties of a short version of Young's Internet Addiction Test. Comput Human Behav. 2013; 29:1212-23.

14.)Kutlu M, Savcı M, Demir Y, et al. Young İnternet Bağımlılığı Testi Kısa Formunun Türkçe uyarlaması: Üniversite öğrencileri ve ergenlerde geçerlilik ve güvenilirlik çalışması. Anadolu Psikiyatri Dergisi. 2016; 17: 69-76.

15.)Cerit B, Çıtak Bilgin N, Ak B. Relationship between smartphone addiction of nursing department students and their communication skills. Contemp Nurse. 2018;54:532-542.

16.)Serin EK, Durmaz YÇ, Polat HT. Correlation between smartphone addiction and dysfunctional attitudes in nursing/ midwifery students. Perspect Psychiatr Care. 2019;55:703-9. 17.)Sunhee L, Hye-Jin K, Han-Gyo C, et al. Smartphone Addiction and Interpersonal Competence of nursing students. Iran J Public
Health. 2018; 47 :342-9.

18.)Prakash S. Internet addiction among junior doctors: A Crosssectional study. Indian J Psychol Med. 2017;39:422-5.

19.)Rafiee $F$, Zare $Z$, Adib-Hajbaghery, $M$ et al. Internet addiction and psychological strain in nursing and midwifery students. Nurs Midwifery Stud. 2020;9: 36-42.

20.)Haque M, Rahman NAA, Majumder MAA et al. Internet use and addiction among medical students of Universiti Sultan Zainal Abidin, Malaysia. Psychol Res Behav Manag. 2016;9:297-307.

21.)ElSalhy M, Miyazaki T, Noda Y, et al. Relationships between Internet addiction and clinicodemographic and behavioral factors. Neuropsychiatr Dis Treat. 2019;15:739-52.

22.)Ayar D, Bektas M, Bektas I, et al. The effect of adolescents internet addiction on smartphone addiction. J Addict Nursg. 2017;28: 210-4.

Ankara Eğt. Arş. Hast. Derg. (Med. J. Ankara Tr. Res. Hosp.), 2021 ; 54(2) : 214-218

For this research, approval from the ethics committee of Diyarbakır Gazi Yaşagil Education and Treatment Hospital was received on 25.10.2019, desicion no: 357 . 